\title{
PERAN PUSAT LAYANAN INTERNET KECAMATAN DALAM UPAYA MENYETIMULI MASYARAKAT MENUJU DESA WISATA
}

\author{
Sumarsono Soemardjo \\ Puslitbang Literasi dan Profesi, Balitbang SDM Kominfo \\ Jl Merdeka Barat 9, Jakarta. HP. 0817372977. E-mail: sumarsonobppisby @ yahoo.com. \\ Naskah diterima tanggal 5 Mei 2014, direvisi tanggal 28 Mei 2014, disetujui tanggal 4 Juni 2014
}

\section{INCREASING THE ROLE OF THE INTERNET SERVICE CENTER IN DISTRIC TO STIMULI THE SOCIETY TOWARDS TOURISM VILLAGE}

\begin{abstract}
The use of internet was expanding, reaching various lines of human life, including ecotourism development sector. However, internet as a tool as well as an enabler, occasionally are less contributing to better accomplish human activity since various determinants which underestimated. Related to that, the government has made programs to expand internet access to rural areas in order to introduce innovation and creating opportunities through the construction of the District Internet Service Centre (PLIK). The research question is how the role of the District Internet Service Centre (PLIK) as stimuli for the rural community to develop a tourism village. The purpose of this research is to analyze the role of PLIK to stimuli the rural community to develop the tourism village. This research reveals how the internet could represent as a stimuli for the rural community to develop a tourism village. In addition, the approach of the research is qualitative. Data gathering through in-depth interview with purposive chosen key informants. The result indicates that the role of the internet can be increased to develop a tourism village through various activities of information dissemination and giving encouragement and transformation value of "sapta pesona" to the local rural community.
\end{abstract}

Keywords: internet, stimuli, tourism village.

\begin{abstract}
Abstrak
Pemanfaatan internet semakin meluas merambah berbagai lini kehidupan manusia termasuk bidang pengembangan ekowisata. Walaupun demikian internet baik sebagai tool maupun enabler kadangkala memang kurang dapat membantu menyelesaikan secara baik, pekerjaaan manusia karena berbagai determinan yang kurang diperhitungkan. Sehubungan dengan hal itu maka pemerintah telah membuat program-program untuk memperluas akses internet ke perdesaan guna memperkenalkan inovasi dan menciptakan kesempatan berusaha melalui pembangunan Pusat Layanan Internet Kecamatan (PLIK). Permasalahan penelitian ini bagaimana peran Pusat Layanan Internet Kecamatan (PLIK) dalam menyetimuli masyarakat perdesaan untuk mewujudkan desa wisata? Tujuan penelitian ini adalah ingin menganalisis peran PLIK dalam menyetimuli masyarakat perdesaan untuk mewujudkan desa wisata. Pendekatan penelitian ini ialah kualitatif. Penggalian data dilaksanakan dengan wawancara mendalam dengan informan kunci yang dipilih secara purposif. Hasil penelitian menunjukkan bahwa peran internet dapat ditingkatkan untuk mewujudkan desa wisata dengan berbagai kegiatan diseminasi informasi dan memberikan motivasi serta transformasi nilai "Sapta Pesona" pada masyarakat desa setempat.
\end{abstract}

Kata kunci: internet, stimuli, desa wisata. 


\section{PENDAHULUAN}

Internet merupakan salah satu teknologi canggih hasil penemuan abad 20 yang sangat bermanfaat bagi kehidupan manusia. Aplikasi internet terus dikembangkan sejalan dengan imaginasi dan kebutuhan manusia yang kadang sangat muluk, abstrak, dan tanpa batas. Sebagaimana sifat teknologi pada umumnya, internet tidak pernah berhenti berkembang dan selalu beradaptasi dengan masyarakat penggunaanya. Teknologi akan selalu bergerak dari satu fase ke fase lainnya. Ia akan mengikuti siklus dari fase earlytransition- matureearly dan begitu seterusnya (Suhartanto, et al, 2010).

Internet yang telah dikembangkan seperti sekarang ini dimulai pemanfaatannya sejak tahun 1969 di lingkungan intern Advanced Research Projects Agency (ARPANET). Pada saat itu telah mulai digunakan jaringan Komputer TCP/IP (Transmission Control Protocol/ Internet Protocol) untuk mengirimkan pesan-pesan antara lembaga pertahanan Amerika Serikat dengan laboratorium-laboratorium riset terkait. Hubungan antarlembaga ini terus berkembang semakin luas dengan melibatkan berbagai kelompok akademik dan kelompok terorganisir di masyarakat yang kemudian pada tahun 1991 bersamaan dengan munculnya World Wide Web pemanfaatan internet semakin meluas dan terbuka untuk umum (Straubhaar dan La Rose, 2001).

Pada dekade terakhir ini secara dramatis internet telah menransformasi dunia, mendifusi inovasi dan meningkatkan produktivitas, menghubungkan manusia dan masyarakat, meningkatkan standar hidup dan menciptakan berbagai kesempatan berusaha bagi manusia di muka bumi. Teknologi Informasi dan Komunikasi juga telah terbukti menjadi kunci pra kondisi untuk meningkatkan daya saing dan ekonomi. Peran internet yang demikian besar terjadi karena selain makin meluasnya jaringan dan infrastruktur yang dibangun juga semakin meningkatnya jumlah penggunanya. Berdasarkan data dari Internet World Stats, dalam satu dasawarsa terakhir jumlah pengguna internet (netter) di dunia meningkat drastis, dari $0,4 \%$ pengguna dari seluruh penduduk dunia pada tahun 1995, naik hampir 60 kali lipat pada 2008. Sejak tahun 2000 , pertumbuhan netter dunia naik rata-rata $2 \%$ per tahun terhadap total populasi dunia (Suhartanto, et al, 2010).

Sehubungan dengan kondisi dan peranan internet seperti tersebut, maka beberapa badan dunia bersama pemerintah di berbagai negara telah membuat programprogram untuk memperluas akses internet ke perdesaan guna memperkenalkan inovasi dan menciptakan kesempatan berusaha. Beberapa program internet masuk desa yang cukup dikenal di antaranya Telecenter, Warung Internet Perdesaan (Wardes), Balai Informasi Masyarakat (BIM), Desa (Punya Internet (Desa Pinter), Pusat Layanan Internet Kecamatan (PLIK), dan lain-lain. Programprogram yang pada dasarnya merupakan penyediaan sarana dan akses internet tersebut tentu diharapkan dapat diintegrasikan dengan program lain yang ada di perdesaan agar memiliki dampak positif yang lebih luas. Salah satu program perdesaan yang menarik dan mulai banyak dikembangkan di beberapa perdesaan akhir-akhir ini adalah kegiatan ekowisata yaitu kegiatan pariwisata yang berbasis lingkungan alam perdesaan. Ekowisata dianggap sebagai salah satu cara yang sesuai untuk meningkatkan kehidupan ekonomi masyarakat perdesaan karena dianggap bisa membuka kesempataan kerja, kesempatan berusaha, serta meningkatkan pengembangan kemampuan berusaha Scheyvens (2000) sekaligus menjaga kelestarian sumber daya alam tertentu. Kegiatan ekowisata ini dapat menyetimulasi dan menumbuhkan perekonomian masyarakat karena ekowisata merupakan industri yang dapat menggerakkan beberapa sektor ekonomi secara simultan seperti transportasi, kuliner, kesenian dan kerajinan rakyat, olah raga dan petualangan, dan lain-lain.

$$
\text { Mengingat pentingnya program }
$$
ekowisata dan peranan internet yang begitu besar maka pengintegrasian antara keduanya diharapkan akan membantu menyelesaikan segala urusan masyarakat dalam mewujudkan desa wisata. Apalagi sarana dan akses internet juga sudah tersedia di banyak perdesaan di 
mana PLIK (Pusat Layanan Internet Kecamatan ) dan Desa Pinter telah dibangun di 32 provinsi dengan total nilai kontrak Rp1.152.912.000. PLIK tersebut memiliki kelengkapan sarana berupa komputer beserta peripheralnya serta akses internet yang memiliki kemampuan kecepatan transfer data minimal 56 Kbps dari CPE (Customer Premises Equipment) ke perangkat operator, latency: maks $750 \mathrm{~ms}$ dari CPE ke IIX (Indonesia Intenet Exchange) dan Paket loss: 2\% dari CPE ke IIX (Kemkominfo, 2010).

Permasalahan yang dirumuskan dalam penelitian ini ialah bagaimana peran Pusat Layanan Internet Kecamatan (PLIK) dalam menyetimuli masyarakat perdesaan untuk mewujudkan desa wisata? Tujuan penelitian ini adalah ingin menganalisis peran PLIK dalam menyetimuli masyarakat perdesaan untuk mewujudkan desa wisata. Manfaat penelitian ini adalah memberikan masukan kepada Dirjen Aptika Kementerian Komunikasi dan Informatika RI tentang pemanfaatan internet sebagai stimulator pengembangan perdesaan. Memberi masukan kepada semua pihak terutama pengelola PLIK sebagai upaya meningkatkan peranannya dalam menyetimuli dan membantu masyarakat sekitarnya untuk meningkatkan kesejahteraannya melalui program-program tertentu yang dalam hal ini desa wisata.

\section{LANDASAN KONSEP}

\section{Penelitian Terdahulu}

Telah banyak penelitian terkait dengan internet untuk masyarakat perdesaan, yang di antaranya dilakukan oleh Unesco bekerja sama dengan Virtual System Procesing (2006) yang berjudul The Socio-economic impact of ICTs in rural Iran. Penelitian tersebut membahas tentang impact dari telecenter terhadap peningkatan kesejahteraan masyarakat atau pada sosio-ekonominya. Hasil penelitian menunjukkan bahwa pendekatan pada masyarakat beserta tokohtokoh setempat baik formal maupun non formal, sektor swasta, dan pemerintahan desa dalam pembangunan dan pengelolaan
Telecenter dianggap sangat penting dan menentukan. Sedangkan dalam operasionalnya, khususnya pada awal berdirinya telecenter perlu diupayakan untuk mengajak para pemuda, wanita, dan anggota masyarakat lainnya agar tidak canggung datang dan sering memanfaatkan telecenter untuk mencari informasi. Selain itu para pengelola telecenter harus punya strategi untuk meningkatkan efektivitas dari telecenter tersebut.

Penelitian serupa juga pernah dilakukan pada Balai Informasi Masyarakat (BIM) di desa Cihideung yang berada di pinggiran kota Bandung. Penelitian ini berupaya mengungkap bagaimana BIM dapat memberdayakan masyarakat melalui informasi serta mengatasi berbagai permasalahan yang dihadapinya. Hasil penelitian menunjukkan bahwa BIM belum banyak dimanfaatkan oleh penduduk sekitarnya yang pada umumnya terdiri dari para petani bunga. Sebagai petani tradisional mereka masih merasa sulit dan enggan untuk memanfaatkan internet, sehingga diperlukan bantuan dan bimbingan orang lain khususnya fasilitator infomobilisasi yang aktif. Dengan demikian terjadi pembelajaran-pembelajaran serta jalinan hubungan ataupun interaksi positif dengan masyarakat sekelilingnya yang pada dasarnya telah memiliki potensi untuk dikembangkan lebih lanjut (Sumarsono, 2009).

Kini internet tidak saja dimanfaatkan sebagai penyebaran informasi ke masyarakat tetapi sudah dimanfaatkan secara sistematis untuk peningkatan pelayanan masyarakat, berbisnis, berpolitik, kegiatan keagamaan, dan lain-lain. Walaupun pemanfaatan internet semakin meluas dengan investasi yang semakin besar namun masih ada orang yang meragukan apakah efektivitas dan kontribusi internet untuk tujuan-tujuan seperti tersebut di atas efektif.

Beberapa studi di negara-negara sedang berkembang seperti di Malaysia dan Nigeria yang dilakukan oleh Kuppusamy and Solucis (2005) Kuppusamy and Shanmugam (2007) bahwa Malaysia pada periode 1975-2002 dan 1983-2004 masing-masing menunjukkan 
bahwa investasi ICT secara statistik meningkatkan pertumbuhan ekonomi. Sedangkan di Nigeria yang berinvestasi besar-besaran untuk mengintegrasikan ICT ke seluruh sektor ekonomi hasilnya cukup menggembirakan walaupun masih ada beberapa faktor yang harus mendapat perhatian agar pembangunan ICT di Nigeria lebih berhasil yaitu: peningkatan keandalan aliran listrik, illiteracy, hambatan budaya, seluk-beluk teknologi, kecepatan akses, dan peran provider yang kurang memadai akibat dari masih mahalnya biaya akses internet (Okogun O.A, et al, 2012).

Berbeda dengan penelitian kali ini, berbagai contoh studi di atas lebih banyak menggali data tentang efektivitas dan kontribusi internet melalui PLIK dalam meningkatkan kinerja suatu lembaga serta efektivitasnya dalam memberdayakan masyarakat. Pada penelitian kali ini akan mencari solusi bagaimana agar masyarakat perdesaan dapat distimuli melalui internet dalam rangka mewujudkan desa wisata yang pada gilirannya dapat meningkatkan kesejahteraan mereka.

\section{Pusat Layanan Internet Kecamatan (PLIK)}

PLIK ialah sarana umum yang dapat dimanfaatkan untuk mengakses internet yang dibangun di ibukota kecamatan sebagai implementasi dari pelaksanaan program Universal Service Obligation (USO) di wilayah tersebut internet kecamatan tidak hanya berfungsi sebagai ruang akses yang dimanfaatkan untuk mengakses internet saja akan tetapi juga untuk mendorong peningkatan konten produktif dan menjadikan portal konten-konten yang bermanfaat. Konfigurasi dari arsitektur jaringan yang disyaratkan untuk menuju ke server kontenkonten yang berada di Jakarta tersebut adalah sebesar 256 kbps untuk downlink dan 128 kbps, untuk uplink sehingga memungkinkan untuk memberikan layanan yang bersifat interaktif. Pembanguan PLIK ini dimulai pada tahun 2010 dengan target jumlah titik layanan lebih dari 5.748 titik. Pengoperasian PLIK dikendalikan oleh Sistem Informasi
Managemen dan Monitoring Internet Kecamatan yang berfungsi antara lain mendukung layanan internet sehat dan aman (INSAN) di setiap PLIK, mengatur dan menyebarkan konten, Komunikasi PLIK, yaitu kemampuan untuk melakukan instant messaging (data, voice, video) dan layanan surat elektronik/ electronic mail (e-mail) yang dapat digunakan antar pelanggan/user PLIK secara aman, serta optimal bandwidth (Meiningsih, dkk, 2012).

\section{Desa Wisata}

Sebagai daerah wisata tentu harus memiliki berbagai daya tarik, agar dapat menarik wisatawan mengunjungi daerah tersebut. Desa wisata sendiri diartikan sebagai suatu wilayah yang menawarkan keseluruhan suasana yang mencerminkan keaslian perdesaan, baik dari segi sosial budaya, adatistiadat, keseharian, arsitektur tradisional, struktur tata ruang desa, serta memunyai potensi untuk dikembangkan berbagai komponen kepariwisataan, misalnya: atraksi, makan-minum, cinderamata, penginapan, dan kebutuhan wisata lainnya (Putra, 2006).

Untuk menjadi suatu daerah tujuan wisata, agar dapat menarik dan dikunjungi wisatawan, harus memiliki tiga syarat, yakni: 1) Daerah ini harus memunyai something to see, artinya di tempat tersebut harus ada objek wisata dan atraksi wisata yang berbeda dengan yang dimiliki oleh daerah lain, daerah tersebut harus memunyai daya tarik khusus;

2) Di daerah tersebut harus tersedia something to do, artinya di daerah tersebut di samping banyak yang dapat dilihat, harus pula disediakan fasilitas rekreasi yang dapat membuat wisatawan betah tinggal lebih lama di tempat itu; 3) Di daerah tersebut harus ada something to buy, artinya di tempat itu harus ada fasilitas untuk dapat berbelanja, terutama souvenir kerajinan masyarakat setempat sebagai kenang-kenangan (Putra, 2006).

Kementerian Kebudayaan dan Pariwisata saat itu juga mengeluarkan program Sapta Pesona di mana Sapta Pesona merupakan prasyarat bagi setiap daerah tujuan wisata yang meliputi: Pertama, aman, yakni suatu kondisi di mana wisatawan 
merasa terlindungi dan bebas dari: a. Tindak kejahatan, kekerasan, ancaman seperti kecopetan, pemerasan, penodongan, dan penipuan dan lain sebagainya; b. Terserang penyakit menular dan penyakit berbahaya lainnya; c. Kecelakaan yang disebabkan oleh alat perlengkapan dan fasilitas yang kurang baik, seperti kendaraan, peralatan untuk makan dan minum, lift, alat perlengkapan atau rekreasi dan olah raga; d. Gangguan oleh masyarakat antara lain berupa pemaksaan oleh pedagang asongan, tangan jahil, ucapan dan tindakan serta perilaku yang tidak bersahabat, dan lain sebagainya. Jadi aman berarti terjamin keselamatan jiwa dan fisik, termasuk milik (barang) wisatawan.

Kedua, tertib, yakni suatu kondisi yang mencerminkan suasana tertib dan teratur serta disiplin dalam semua segi kehidupan masyarakat baik dalam hal lalu lintas kendaraan, penggunaan fasilitas maupun dalam berbagai perilaku masyarakat lainnya, misalnya: a. Lalu lintas tertib, teratur, dan lancar alat angkutan datang dan berangkat tepat pada waktunya; b. Tidak tampak orang yang berdesakan atau berebut mendapat atau membeli sesuatu yang diperlukan; c. Bangunan dan lingkungan ditata teratur dan rapi; d. Informasi yang benar dan tidak membingungkan.

Ketiga, bersih, yaitu kondisi yang memperlihatkan sifat bersih dan higienis baik keadaan lingkungan, sarana pariwisata, alat perlengkapan pelayanan maupun manusia yang memberikan pelayanan tersebut. Wisatawan akan merasa betah dan nyaman bila berada di tempat tempat yang bersih dan sehat seperti: a. Lingkungan yang bersih baik dirumah sendiri maupun di tempat umum, hotel, restoran, angkutan umum, tempat rekreasi, tempat buang air kecil/besar; b. Sajian makanan dan minuman yang bersih dan sehat; c. Penggunaan dan penyediaan alat perlengkapan yang bersih; d. Pakaian dan penampilan petugas bersih, rapi, dan tidak mengeluarkan bau tidak sedap.

Keempat, sejuk, yaitu terciptanya suasana yang segar, sejuk serta nyaman yang dikarenakan adanya penghijauan secara teratur dan indah baik dalam bentuk taman maupun penghijauan di setiap lingkungan tempat tinggal, untuk itu hendaknya semua warga: a. Turut serta aktif memelihara kelestarian lingkungan dan hasil penghijauan yang telah dilakukan masyarakat ataupun pemerintah; b. Berperan secara aktif untuk menganjurkan dan memelopori agar masyarakat setempat melaksanakan kegiatan penghijauan dan memelihara kebersihan, menanam berbagai tanaman di halaman rumah masing-masing baik untuk hiasan maupun tanaman yang bermanfaat bagi rumah tangga, di halaman sekolah, dan lain sebagainya; Membentuk perkumpulan yang bertujuan memelihara kelestarian lingkungan; c. Menghiasi ruang belajar / kerja, ruang tamu, ruang tidur, dan tempat lainnya dengan aneka tanaman penghias atau penyejuk. d. Memrakarsai berbagai kegiatan dan upaya lain yang dapat membuat lingkungan hidup kita menjadi sejuk, bersih, segar, dan nyaman.

Kelima, indah, yaitu kondisi yang mencerminkan penataan yang teratur, tertib, dan serasi baik mengenai prasarana, sarana, penggunaan tata warna yang serasi, selaras dengan lingkungannya serta menunjukkan sifat-sifat kepribadian nasional. Indah yang selalu sejalan dengan bersih dan tertib dan tidak terpisahkan dari lingkungan hidup baik berupa ciptaan Tuhan Yang Maha Esa maupun hasil karya manusia. Karena itu warga wajib memelihara lingkungan hidup agar lestari dan dapat dinikmati oleh umat manusia.

Keenam, ramah tamah, yaitu sikap dan perilaku masyarakat yang ramah dan sopan dalam berkomunikasi, memberikan pelayanan serta ringan tangan untuk membantu tanpa pamrih. Ramah tamah merupakan watak dan budaya bangsa Indonesia pada umumnya, selalu menghormati tamunya dan dapat menjadi tuan rumah yang baik. Sikap ramah tamah ini merupakan salah satu daya tarik bagi para wisatawan, oleh karena itu harus dipelihara terus.

Ketujuh, kenangan, yaitu kesan yang menyenangkan dan akan selalu diingat. Kenangan dapat berupa yang indah dan menyenangkan, akan tetapi dapat pula yang tidak menyenangkan. Kenangan yang ingin diwujudkan dalam ingatan dan perasaan wisatawan dari pengalaman berwisata, 
dengan sendirinya adalah yang menyenangkan. Kenangan yang indah ini dapat pula diciptakan dengan antara lain: a. Akomodasi yang nyaman, bersih, dan pelayanan yang cepat, tepat, dan ramah; b. Atraksi-atraksi budaya khas yang memesona; c. Jenis makanan khas daerah yang lezat dengan penampilan dan penyajian yang menarik dan higienis; d. Cindera mata yang merupakan ciri khas daerah dengan tampilan yang indah dan harga yang murah (Dinas Pariwisata Kebudayaan Pemuda dan Olah Raga Kab. Sidoarjo, 2010).

\section{Teori Difusi Inovasi}

Secara teoretis pemberian fasilitas akses internet pada masyarakat perdesaan pada dasarnya adalah merupakan sebuah difusi inovasi yaitu memperkenalkan suatu peralatan dan cara kerja yang baru bagi masyarakat yang sebelumnya tidak pernah dilakukannya.

Banyak definisi inovasi dan banyak pula kegiatan yang dapat dikategorikan sebagai inovasi namun pada prinsipnya inovasi adalah kesuksesan ekonomi dan sosial berkat diperkenalkannya cara baru atau kombinasi baru dari cara-cara lama dalam menransformasi input menjadi output yang menciptakan perubahan besar dalam hubungan antara nilai guna dan harga yang ditawarkan kepada konsumen dan/atau pengguna, komunitas, sosietas, lingkungan. Disarikan dari Goswami dan Mathew, PDMA, De Meyer dan Garg, Senge, dkk (Avanti, 2009).

Pengenalan internet kepada masyarakat perdesaan pada dasarnya adalah memperkenalkan inovasi yang tidak sederhana seperti inovasi ide-ide baru yang lainnya. Sebab internet yang diperkenalkannya ini merupakan teknologi canggih yang tidak hanya berfungsi sebagai tool atau peralatan tetapi juga sebagai enabler membantu menciptakan yang tadinya tidak ada menjadi ada, yang tidak mungkin menjadi mungkin.

Teori Difusi Inovasi mengungkapkan bahwa terjadinya inovasi melalui beberapa tahapan dan tidak semua inovasi akan dengan mudah diterima masyarakat perdesaan. Proses adopsi inovasi menurut ahli sosiologi perdesaan melalui tahapan-tahapan sebagai berikut: 1) Tahap kesadaran, di mana seseorang mengetahui adanya ide-ide baru tetapi kekurangan informasi mengenai hal itu; 2) Tahap menaruh minat, di mana seseorang mulai menaruh minat terhadap inovasi dan mencari informasi lebih banyak mengenai inovasi itu; 3) Tahap penilaian, di mana seseorang mengadakan penilaian terhadap ide baru itu dihubungkan dengan situasi dirinya sendiri saat ini dan masa mendatang dan menentukan mencobanya atau tidak; 4) Tahap pencobaan, di mana seseorang menerapkan ide-ide baru itu dalam skala kecil untuk menentukan kegunaannya, apakah sesuai dengan situasi dirinya; 5) Tahap penerimaan, di mana seseorang menggunakan ide baru itu secara tetap dalam skala yang luas (Rogers, 1995).

Pada kenyataannya sebuah inovasi tidaklah selalu berakhir pada adopsi, ada kalanya juga ditolak dan masih berlanjut dengan pencarian informasi sebagai upaya pengukuhan. Selain itu proses adopsi juga tidak semudah itu, yang selalu melalui tahapan yang berurutan. Oleh karena itu Rogers menyusun paradigma proses keputusan inovasi yang terdiri dari 4 (empat) tahap sebagai berikut:

1. Pengenalan, di mana seseorang mengetahui adanya inovasi dan memeroleh beberapa pengertian tentang bagaimana inovasi itu berfungsi;

2. Persuasi, di mana seseorang membentuk sikap berkenan atau tidak berkenan terhadap inovasi;

3. Keputusan, di mana seseorang terlibat pada kegiatan yang membawanya pada pemilihan untuk menerima atau menolak inovasi;

4. Konfirmasi, di mana seseorang mencari penguat bagi keputusan inovasi yang telah dibuatnya. Pada tahap ini mungkin terjadi seseorang mengubah keputusannya jika ia memeroleh informasi yang bertentangan (Rogers, 1995). 
Secara lebih lengkap proses difusi inovasi dengan segala tahapan dan berapa hal yang melingkupinya dapat dilihat pada model berikut ini.

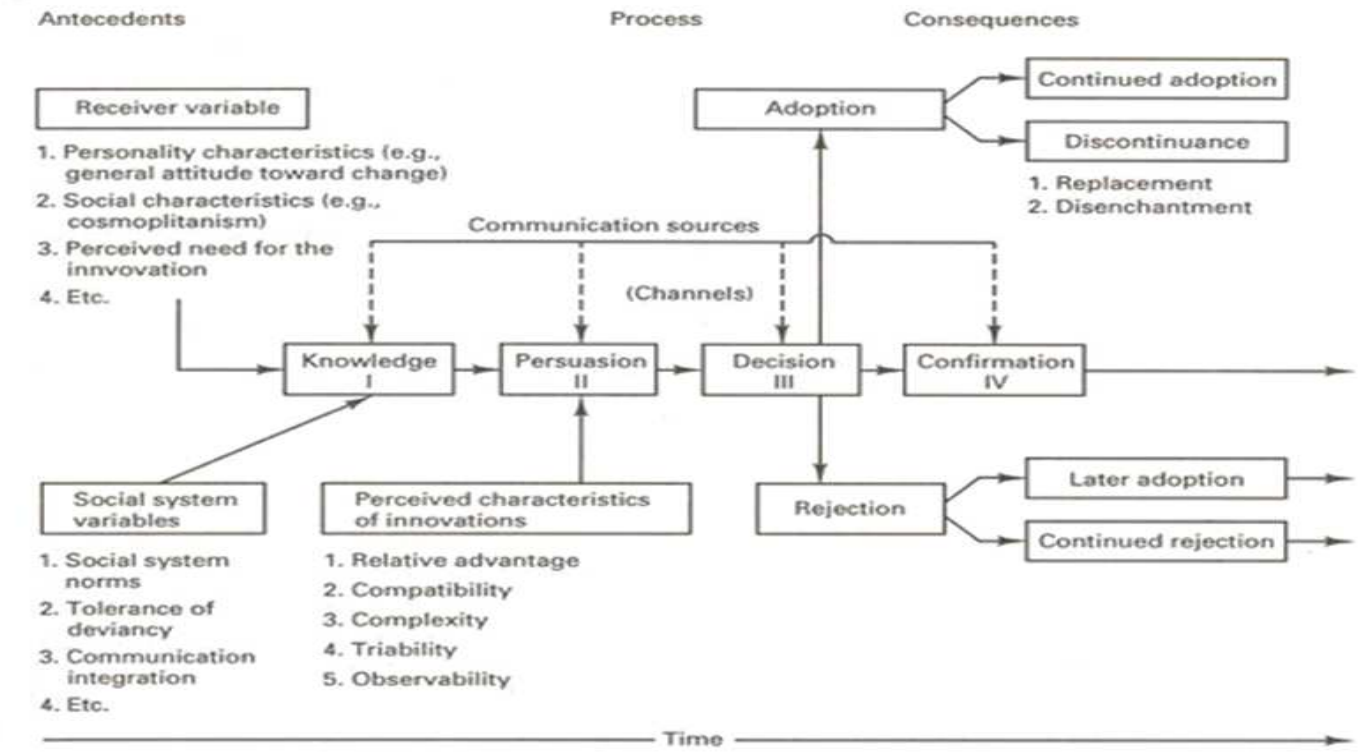

Sumber: Rogers (1995)

\section{Gambar 1 \\ Diffusion of Innovation Model}

Penerima inovasi yang dalam hal ini masyarakat perdesaan secara pribadi dalam menghadapi difusi inovasi ditentukan oleh beberapa variabel (gambar 1) yang antara lain: karakteristik kepribadiaannya (personality characteristics) seperti sikapnya terhadap suatu perubahan. Selain itu juga ditentukan oleh karakteristik sosialnya (social characteristic) seperti sikap kosmopolit, dan lain-lain, serta ditentukan juga oleh kebutuhan akan inovasi itu sendiri (perceived need for the innovation), dan lain-lain.

Di sisi lain penolakan terhadap suatu inovasi ditentukan oleh variabel sistem sosial yang meliputi antara lain norma-norma sistem sosial (social system norms), toleransi terhadap penyimpangan (tolerance of deviancy), komunikasi yang terintegrasi (communication integration), dan lain-lain.

\section{METODE PENELITIAN}

Penelitian ini menggunakan metode kualitatif (qualitative approach) dengan pendekatan studi kasus, penggalian data dilakukan dengan wawancara mendalam dengan informan kunci (keyperson) yang dianggap menguasai permasalahan. Pendekatan studi kasus dipilih karena pokok permasalahan yang diteliti sangat kompleks dan abstrak memiliki keterkaitan dengan budaya, nilai/norma, sikap, dan perilaku serta kemauan dan kemampuan masyarakat setempat dalam mengadopsi teknologi informasi untuk mewujudkan desa wisata.

Pengumpulan data dilaksanakan di Kabupaten Malang, Jawa Timur, pemilihan informan kunci dilaksanakan secara purposif yang diharapkan dapat mewakili: perangkat desa, petani/pedagang jeruk, pimpinan kelompok tani, KIM, pejabat terkait, pengelola PLIK/warnet, pengamat atau praktisi teknologi informasi, budayawan, pustakawan, pemilik warnet dan tokoh masyarakat di kota lokasi penelitian. Informan kunci yang berhasil diwawancarai antara lain: 
Tabel 1

Informan Kunci yang diwawancarai

\begin{tabular}{|c|c|c|}
\hline No. & $\mathbf{N} \mathbf{a} \mathbf{m} \mathbf{a}$ & Jabatan/ status \\
\hline$\overline{1}$ & Drs. Widjaja Saleh Putra & Sekretaris Dinas Komunikasi dan Informasi, Kota Malang \\
\hline 2 & Dra Fenny Indriani, MM & Kepala Perpustakaan dan Arsip Daerah Kota Malang \\
\hline 3 & Yunita Rahma Dewi & Pustakawan, Perpustakaan dan Arsip Daerah Kota Malang \\
\hline 4. & Prof. Dr. Toto Nusantara, MSI & $\begin{array}{l}\text { Ketua Lembaga Penelitian dan Pengabdian Kepada } \\
\text { Masyarakat, Universitas Negeri Malang }\end{array}$ \\
\hline 5 & Sutrisno & $\begin{array}{l}\text { Ketua Program Studi Teknologi Informasi dan Ilmu } \\
\text { komputer, (PTIIK) Universitas Brawijaya }\end{array}$ \\
\hline 6 & Drs. Sugianto & $\begin{array}{l}\text { Ketua KIM Purwoagung, Kelurahan Purwantoro, Kec } \\
\text { Blimbing }\end{array}$ \\
\hline 7 & Zainal Abidin, M.Kom & $\begin{array}{l}\text { Kepala Unit Pusat Informasi dan Pangkalan data, } \\
\text { Universitas Islam Negeri, Malang. }\end{array}$ \\
\hline 8 & Sri Muratim & Kepala Desa Tegalweru \\
\hline 9 & Hermawan & Pengelola PLIK, Desa Selorejo. \\
\hline 10 & Bambang Soponyono & Sekretaris Desa Selorejo \\
\hline 11 & Muslimin & Ketua Kelompok Tani Subur Makmur, Desa Selorejo \\
\hline 12 & Suwaji & Pegiat desa wisata petik jeruk, Selorejo. \\
\hline 13 & Wiroyo & Pegawai CV Bueb, pengelola MPLIK Kabupaten Malang \\
\hline
\end{tabular}

Wawancara juga dilakukan kepada pelanggan/pemakai internet di desa lokasi penelitian untuk menggali informasi tentang motivasi dan pengalamannya dalam penggunaan internet. Data yang terkumpul diolah dan dianalisis kemudian disajikan dalam bentuk laporan penelitian. Untuk memperkaya data dan informasi dilakukan pengamatan langsung di lokasi penelitian serta studi kepustakaan.

\section{HASIL PENELITIAN DAN PEMBAHASAN}

\section{Inovasi di Desa Selorejo}

Penduduk Desa Selorejo sebagian besar berpendidikan rendah yaitu sekolah dasar 1.638 orang dan bahkan masih ada yang buta huruf yaitu 98 orang. Mereka menjalankan kehidupannya sehari-hari dengan rutinitasnya sebagai petani, peternak, pedagang, dan lain- lain. Perubahan besar memang pernah dialami oleh warga Desa Selorejo ini yaitu ditahun 1985 di mana seorang tokoh masyarakat yang bernama $H$. Dulawi memperkenalkan tanaman jeruk di desa ini, seperti dikatakan oleh Sekretaris Desa Solorejo:

"Dulunya Desa Selorejo merupakan desa miskin, sebagian penduduknya berpendidikan rendah, dan mata pencahariannya sebagai peternak, petani, maupun pedagang.....hingga kemudian seorang tokoh masyarakat $\mathrm{H}$ Dulawi memperkenalkan masyarakat dengan tanaman jeruk" (Wawancara dengan Bambang Soponyono tgl 25 Oktober 2013, di kantor Desa Selorejo).

Keberhasilan tokoh masyarakat dalam menanam jeruk ini kemudian secara perlahan diikuti oleh para petani sekitarnya. Berkat tanaman jeruk kini penghasilan para petani Selorejo meningkat dan sebagian tergolong menjadi petani sejahtera. Secara rinci tingkat kesejahteraan petani jeruk di desa ini dapat 
dilihat pada tabel berikut ini :

Tabel 2

Tingkat Kesejahteraan Keluarga Penduduk Desa Selorejo

\begin{tabular}{rll}
\hline No. & \multicolumn{1}{c}{ Golongan } & \multicolumn{1}{c}{ Jumlah } \\
\hline 1. & Keluarga pra-sejahtera & $248 \mathrm{KK}$ \\
2. & Keluarga sejahtra I & $671 \mathrm{KK}$ \\
3. & Keluarga sejahtera II & $63 \mathrm{KK}$ \\
4. & Keluarga sejahtera III & $15 \mathrm{KK}$ \\
5 & Keluarga sejahtera III plus & $8 \mathrm{KK}$ \\
\hline
\end{tabular}

Sumber: monografi desa Selorejo tahun 2013

Keberhasilan petani jeruk di Desa Selorejo juga tercermin selain dari rumahrumah tinggal mereka yang besar dan permanen serta banyak di antaranya yang bergaya modern dan mewah dengan rincian sebagai berikut :

Tabel 3

Klasifikasi rumah Penduduk

\begin{tabular}{rlr}
\hline No & Jenis bangunan rumah & Jumlah \\
\hline 1. & Rumah Tembok & 945 buah \\
2. & Rumah Kayu & 15 buah \\
3. & Rumah Bambu & 45 buah \\
\hline
\end{tabular}

Sumber: monografi desa Selorejo tahun 2013

Penduduk Desa Selorejo tidak serta merta ikut-ikutan menanam jeruk di lahan pertaniannya. Seiring dengan berjalannya waktu jeruk-jeruk yang ditanam di lahan $\mathrm{H}$ Dulawi tumbuh dengan baik dan semakin besar. Setelah menunggu selama lebih kurang 4 (empat) tahun maka tanaman jeruk $\mathrm{H}$ Dulawi sudah bisa dipanen dan hasilnya lumayan baik. Keuntungan dari panen jeruk ini makin menjanjikan karena tidak seperti tanaman palawija atau padi di mana setiap kali panen dibabat habis dan berikutnya dimulai tanaman baru dan hal ini akan diulang setiap musimnya. Sehingga setiap musim tanam tiba diperlukan tenaga dan biaya yang tidak sedikit bila mengharapkan hasil panen yang baik.

Memasuki inovasi kedua masyarakat Desa Selorejo memosisikan desanya menjadi desa wisata. Ide pembangunan desa wisata ini awalnya digagas oleh seorang tokoh masyarakat. Seperti dikatakan oleh Sekretaris Desa Bambang Soponyono:

"Setelah berhasil dengan tanaman jeruk, kami mencoba lagi untuk mengembangkan desa ini menjadi desa wisata, ya..... itung-itung mengembangkan pemasaran jeruk di desa ini, sehingga orang 
tidak hanya mengenal desa ini sebagai penghasil jeruk saja....." (Wawancara dengan Bambang Soponyono, tanggal 25 Oktober 2013, di kantor Desa Selorejo).

Potensi wisata desa ini memang cukup baik di mana Desa Selorejo terletak sekitar 15 $\mathrm{Km}$ dari kota Malang dan $5 \mathrm{Km}$ dari kota Batu yang lebih dahulu telah menjadi kota wisata.

\section{Pusat Layanan Internet Kecamatan (PLIK)}

Penempatan PLIK di Desa Selorejo sangat tepat, karena Desa Selorejo merupakan desa yang letaknya agak terpencil namun cukup padat penduduknya. Kehadiran PLIK tentunya akan sangat bermanfaat karena masyarakat bisa mengakses informasi melalui internet. Awalnya penempatan PLIK berada di kantor Desa Tegalweru, namun di tempat tersebut PLIK kurang dimanfaatkan secara optimal. Dengan jumlah komputer yang hanya 6 (enam) sebenarnya masih kurang, dibandingkan dengan jumlah penduduk di Desa Selorejo yang cukup padat. Namun PLIK sudah cukup mampu memberikan akses informasi bagi penduduk di sekitarnya.

Berdasarkan pengamatan peneliti, pengunjung PLIK adalah para pelajar SD sampai SMA. Tujuan mereka mendatangi PLIK adalah untuk mencari bahan tambahan untuk pelajaran di sekolah. Selebihnya mereka memanfaatkan internet untuk bermain game. Waktu yang disediakan untuk mengunjungi PLIK khusus untuk anak SD hingga pukul 16.00 WIB, hal tersebut dimaksudkan agar tidak mengganggu jam belajar mereka. Berkaitan dengan aktivitas anak SD dalam menggunakan internet, pengelola PLIK Desa Selorejo mengatakan:

"Main game bagi anak-anak dianggap wajar karena seumur mereka memang memerlukan permainan dan hal itu dapat menumbuhkan rasa senang dan gemar untuk berinternet" (Wawancara dengan Hermawan tanggal 29 Oktober 2013, di kantor PLIK Desa Selorejo ).

PLIK di Desa Selorejo ini terlihat dapat beroperasi dengan lancar, pengunjungnya banyak. Semuanya terjadi berkat keuletan pengelolanya. Hal tersebut terjadi pertama karena di desa tersebut belum ada usaha warnet dan kedua karena keinginan masyarakat untuk mendapatkan informasi melalui internet. Hal tersebut sangat wajar mengingat internet merupakan gudangnya informasi. Informasi apapun bisa didapatkan melalui internet.

Tidak dapat dipungkiri bahwa sebagai alat internet perlu dipelihara baik dari sisi hardwarenya maupun dari sisi softwarenya. Hal itulah yang kadang menjadi kendala dalam mengelola PLIK. Karena pemerintah dalam hal ini Kemenkominfo hanya sekedar memberikan perangkat komputer dan akses internetnya, namun pemeliharaan diserahkan pada masing-masing desa penerima. Sementara sumber daya manusia yang menguasai teknologi tersebut kadang-kadang tidak tersedia. Namun Desa Selorejo ternyata telah memunyai sumber daya manusia yang mengerti mengenai teknologi tersebut, seperti dikatakan oleh pengelola PLIK Desa Selorejo:

"Upaya perbaikan kerusakan komputer biasanya saya ditangani sendiri. Beberapa perubahan yang telah saya lakukan ialah mengganti sistem operasi yang semula menggunakan open source kemudian saya ubah menjadi windows yang lebih familier untuk penggunanya" (Wawancara dengan Hermawan, tanggal 29 Oktober 2013, di kantor PLIK Desa Selorejo ).

Selain permasalahan mengenai tidak tersedianya sumber daya manusia yang mengerti teknologi komunikasi dan informasi (teknisi TIK), ada permasalahan lain yang lebih penting yakni tidak adanya kejelasan status kepemilikan terhadap perangkat komputer beserta fasilitas internetnya, pola operasi yang jelas, dan pembina yang nantinya bertanggungjawab bila terjadi permasalahan dan pengembangan ke depan. Seperti dikatakan oleh pengelola PLIK Desa Selorejo:

"Saya merasakan bahwa seakan saya tinggal sendirian untuk menghadapi permasalahan dan berjuang untuk bertahan hidup di masyarakat. Permasalahan lain yang saya rasakan ialah pesatnya perkembangan teknologi informasi sehingga perangkat 
komputer dan servernya perlu diupdate yang lebih canggih dan hemat energi"(Wawancara dengan Hermawan tanggal 29 Oktober 2013, di kantor PLIK Desa Selorejo) .

Meningkatnya langganan daya memang menjadikan kendala tersendiri bagi pengelola PLIK, untuk itu penghematan pemakaian daya telah dilakukan dengan berbagai upaya, di antaranya adalah dengan membatasi pelayanan internet.

\section{Kelompok Tani dan Kebutuhan Informasi Masyarakat}

Sebagian besar penduduk Desa Selorejo adalah petani jeruk, yang penghasilannya tergantung pada jeruk. Oleh karena itu, para petani tersebut berupaya keras untuk selalu membudidayakan jeruk sebaik mungkin agar mendapatkan hasil panen yang melimpah dengan harga yang baik. Berbagai upaya telah dilakukan masyarakat untuk membudidayakan jeruk tersebut, yang di antaranya dengan cara mempersiapkan lahan, memilih bibit yang baik, menanam dengan benar, memberantas hama, memanen, dan berbagai tindakan paska panen. Ke semuanya itu memerlukan dasar pengetahuan dan pengalaman tentang budidaya jeruk. Tidak hanya itu berbagai informasi terbaru juga diperlukan untuk memelihara eksistensi, meningkatkan produktivitas, dan harga yang baik. Seperti dikatakan oleh ketua Kelompok Tani Subur Makmur, Desa Selorejo:

"Untuk sekedar memelihara eksistensi biasanya informasi diperoleh dari teman sesama petani jeruk yang lebih berpengalaman dan diberikan secara gethoktular. Sedangkan untuk peningkatan produktivitas dan paska panen informasi diperoleh dari Penyuluh Pertanian Lapangan (PPL) yang melaksanakan kegiatan, tidak hanya memberikan penyuluhan tetapi juga diklat dan praktik lapangan" (Wawancara dengan Muslimin tanggal 30 Oktober 2013, di kantor Desa Selorejo).

Di Kecamatan Dau terdapat Unit Pelaksana Teknis Daerah (UPTD) Pertanian dan Ketahanan Pangan yang memiliki tugas meningkatkan produktivitas hasil pertanian di wilayahnya. Salah satu upaya yang dilakukan instansi tersebut ialah menyelenggarakan penyuluhan yang dilakukan oleh para Petugas Penyuluh Lapangan (PPL).

Sebelumnya masyarakat terlihat kurang aktif mencari informasi, mereka cenderung menunggu dan meniru atau mengikuti para tetangganya yang panennya berhasil dengan baik. Pemilik lahan ataupun pengusaha tanaman jeruk ini, terdiri dari berbagai golongan seperti pengusaha besar yang menggarap lahan tanaman jeruk lebih dari 2 hektar, golongan yang menggarap lahan kurang dari 2 hektar dan golongan petani penggarap/ buruh tani. Bagi pemilik lahan luas lebih dari 2 hektar ini biasanya lebih bersifat kosmopilit sering bepergian dan memiliki jaringan luas di berbagai kota. Untuk itu mereka selalu menjadi leader dalam hal pembudidayaan tanaman jeruk. Merekalah yang memiliki informasi baru berkaitan dengan budidaya tanaman jeruk dan pemasaran hasilnya. Mereka pulalah yang menjadi panutan dalam hal budidaya tanaman jeruk bagi masyarakat petani jeruk sekitarnya.

Sejak dibentuknya kelompok tani di desa ini, masyarakat mulai aktif berdiskusi untuk memecahkan masalah melalui kelompok tani tersebut. Sebagaimana diketahui di Desa Selorejo terdapat dua kelompok tani yaitu kelompok tani Subur Makmur yang diketuai oleh Muslimin dan kelompok tani Margo Mulyo yang diketuai Suwandi. Masing-masing kelompok tani yaitu Subur Makmur memunyai anggota 85 orang dan untuk kelompok Margo Mulyo beranggotakan 75 orang petani. Struktur organisasi kelompok tani ini telah baku dan mencerminkan berbagai kegiatannya. Ada 6 (enam) seksi yang dimiliki kelompok tani tersebut yakni: seksi pangan, seksi ternak, seksi sayur-mayur, seksi hortikultura, seksi pemasaran, seksi penghubung/humas, dan dilengkapi dengan sekretaris kelompok dan bendahara. Pertemuan biasanya dilakukan sebulan dua kali yaitu awal bulan dan akhir bulan. Forum pertemuan ini selain dimanfaatkan sebagai arisan juga biasanya diisi penyuluhan dari PPL (Wawancara dengan Muslimin tanggal 30 Oktober 2013).

UPTD Pertanian Kecamatan Dau juga pernah melaksanakan sekolah lapangan untuk 
para petani jeruk yang diberikan seminggu sekali selama 3 bulan tiap satu tingkatan, dengan materi mulai dari pembibitan hingga paska panen yang meliputi penyortiran, pengepakan, dan pengiriman.

Oleh karena itu bisa jadi kunjungan masyarakat petani jeruk ke PLIK untuk mencari informasi sangat terbatas. Walaupun diakui masih banyak determinan lain yang membuat nihilnya kunjungan anggota kelompok tani ini ke PLIK yang di antaranya malu dan canggung karena pengunjungnya didominasi anak-anak, atau mungkin juga disebabkan karena telah banyak anggota kelompok tani yang memiliki komputer sendiri, serta masih banyak faktor seperti kenyamanan akses, ketersediaan waktu akses, dan lain-lain.

\section{Keberhasilan Inovasi}

Keberhasilan inovasi ditentukan oleh adanya perubahan nilai atau norma yang ada di masyarakat (Rogers, 1995). Demikian juga seperti yang terjadi pada inovasi tahap pertama di Desa Selorejo atau keberhasilan diadopsinya tanaman jeruk sebagai tanaman pokok di desa tersebut. Sebagaimana diketahui, tanaman padi, jagung, dan palawija sejak lama telah dianggap sebagai tanaman pokok oleh petani di berbagai daerah, karena hasil panennya secara langsung dapat dijadikan makanan pokok sehari-hari.

Petani akan tenteram bila lumbungnya penuh dengan hasil panen dari tanaman pokok. Kegagalan panen tanaman pokok merupakan hal yang sangat tidak diinginkan para petani karena akan membuat mereka menderita kekurangan pangan. Kewajiban menanam padi, jagung, dan palawija sudah dilakukan petani di desa ini secara turun temurun dan telah menjadi sistem nilai (system social norm) yang dianut, sehingga akan dipertanyakan apabila ada petani yang menanami sawahnya dengan tanaman utama selain tanaman padi, jagung, dan palawija ini. Kunci sukses dari perubahan nilai di masyarakat ini karena adanya contoh nyata yang mereka lihat dengan mata kepala sendiri di lapangan, di mana menaman jeruk itu ternyata tidak sulit (complexity) dan lebih menguntungkan (relative advanted) dari pada menanam padi, jagung, dan palawija. Sehingga secara perlahan tetapi pasti masyarakat berangsur-angsur mengadopsi tanaman jeruk sebagai tanaman pokok di desa ini.

Selain contoh nyata yang mereka lihat langsung di lapangan para tokoh masyarakat dan PPL melalui kelompok tani yang ada di desa ini, juga aktif mendorong minat masyarakat untuk menanam jeruk. Kekompakan para tokoh masyarakat dan PPL tersebut, berhasil mengintegrasikan informasi (communication integration) melalui kegiatan-kegiatan penyuluhan dan diskusi rutinnya yang digelar di tiap kelompok sebulan dua kali. Mengingat semua anggota kelompok tani ini adalah petani yang ingin maju maka motivasi mereka untuk mencari, mendiskusikan, dan mempraktikkan berbagai informasi berkaitan dengan tanaman jeruk ini sangat kuat sehingga ikut mendorong terjadinya percepatan inovasi.

Kini inovasi tanaman jeruk telah mengantarkan penduduk Desa Selorejo menjadi masyarakat yang tergolong sejahtera. Apabila inovasi yang kedua yaitu desa wisata ingin berhasil maka setidaknya juga harus ditempuh melalui cara-cara seperti tersebut di atas. Hanya saja yang perlu mendapatkan perhatian ialah kondisi masyarakat yang sebagian besar telah tergolong sejahtera itu menjadi lebih kosmopolit dan terbuka terhadap informasi dari berbagai sumber. Cepat atau lambat gaya hidup masyarakat di Desa Selorejo akan berubah. Oleh karena itu diperlukan agen pembaruan yang lebih hebat dan integrasi informasi yang kuat pula melalui bantuan pembangunan web/portal desa atau media tersendiri.

\section{Meningkatkan Peran Pusat Layanan Internet Kecamatan (PLIK) sebagai Stimulan}

Pengelola PLIK selalu berupaya memperkenalkan kegiatannya pada masyarakat dengan berbagai cara, di antaranya menjadi sponsor gerak jalan yang diselenggarakan di desa tersebut, yang dihadiri oleh bupati dan para pejabat 
setempat.

Banyak spanduk dan leaflet yang disebar di masyarakat terkait kegiatan ini. Selain itu kegiatan tersebut juga diupload di internet. Hal yang demikian diharapkan akan menjadi stimuli bagi masyarakat, dan ke depan, tidak hanya keinginan untuk menemukan foto diri sendiri di internet, namun masyarakat juga diajak untuk mulai menyenangi internet dan mulai memanfaatkannya untuk mencari berbagai informasi sesuai dengan kebutuhannya.

Ada beberapa hal yang menjadi kendala bagi masyarakat di Desa Selorejo untuk memanfaatkan PLIK sebagai tempat untuk mencari informasi: Pertama, minimnya keterampilan penduduk di desa tersebut untuk mengoperasikan komputer sebagai alat untuk mengakses internet; Kedua, belum tersedia petugas lapangan untuk mendidik masyarakat agar tidak buta internet. Seperti yang dikatakan oleh Suwaji, juragan jeruk dan pegiat desa wisata petik jeruk, Desa Selorejo:

"...saya ingin memromosikan Desa

Selorejo melalui berbagai cara dan salah satunya dengan memanfaatkan internet. Oleh karena itu saya membeli laptop tetapi saya belum memiliki keterampilan untuk mengoperasikannya secara baik sehingga laptop yang saya beli cukup mahal tersebut, akhirnya hanya digunakan untuk main game anak saya. Di sisi lain ketika saya, mau belajar internet sendiri tidak tahu harus kemana dan kepada siapa, sedangkan bila ke PLIK saya malu sama anak-anak yang umumnya menjadi pelanggan mayoritas PLIK" " (Wawancara dengan Suwaji, Pegiat Desa wisata petik jeruk, Desa Selorejo tanggal 1 November 2013).

Upaya pendampingan atau pembelajaran internet di perdesaan agaknya memang tidak semudah di perkotaan, di mana sangat banyak ditemukan buku-buku panduan untuk memelajari bagaimana cara mengoperasikan internet, demikian pula dengan pengajar di bidang TIK sangat banyak ditemukan. Melihat kenyataan tersebut dapat dikatakan bahwa PLIK di Desa Selorejo belum dioptimalkan oleh seluruh masyarakat di desa tersebut, karena fungsinya masih sama dengan warnet yang hanya menyediakan perangkat dengan fasilitas internet, dan hanya dikunjungi oleh anak SD hingga SMA.

\section{PENUTUP}

\section{Simpulan}

Internet sebagai stimulan masyarakat akan dapat berjalan dengan baik apabila masyarakat telah memiliki kesadaran bahwa informasi itu penting dan dibutuhkan untuk memecahkan permasalahan yang dihadapinya. Melalui internet segala upaya dapat menjadi mudah, efektif, dan efisien. Namun untuk dapat memanfaatkan internet secara baik masyarakat terlebih dahulu juga harus punya skill atau keterampilan untuk mengoperasikan internet. Bila kedua hal tersebut di atas belum dimiliki masyarakat, tentunya harus ada upaya pendampingan atau pembelajaran terlebih dahulu melalui voluntary maupun penugasan atau mempekerjakan (hired) orang atau lembagalembaga pemberdayaan masyarakat tertentu.

Bilapun berbagai persyaratan tersebut telah dipenuhi peningkatan kesejahteraan bagi masyarakat perdesaan melalui internet tidaklah terjadi serta-merta dan segera dapat dinikmati tetapi akan melalui jalan panjang, sebagaimana sebuah inovasi yang kadang mendapatkan penolakan dari masyarakat sendiri.

Kehadiran PLIK di Desa Selorejo belum banyak membantu masyarakat untuk memanfaatkan internet sebagai media penyuplai informasi, karena keterbatasan pengetahuan dan keterampilan masyarakat untuk mengoperasikan komputer dengan fasilitas internet. PLIK di Desa Selorejo masih berfungsi sebagai warnet, dan baru dimanfaatkan oleh anak-anak SD hingga SMA untuk mencari tugas-tugas sekolah dan bermain game.

\section{Saran}

Agar internet di Desa Selorejo (PLIK) dapat berfungsi maksimal maka selain diperlukan agen perubahan (inovator) hendaknya juga perlu dibentuk relawan pendamping masyarakat untuk melakukan 
pembelajaran dan sekaligus dapat menyaring dan mengolah informasi dari internet yang bermanfaat bagi masyarakat.

Perlu dibentuk jaringan kerjasama antara pengelola PLIK dengan semua pihak terutama para tokoh masyarakat setempat baik yang tergabung dengan kelompok tani maupun yang lainnya agar terjadi sinergi dalam mewujudkan desa wisata.

Perlu dibentuk paguyuban atau asosiasi PLIK agar dapat saling bertukar informasi dan berkoordinasi antarpengelola PLIK di daerah. Selain itu agar kegiatan operasional PLIK lebih terarah dan berdayaguna juga diperlukan pembina PLIK yang bertugas memberikan arahan dan perlindungan bagi pengelola PLIK di daerah.

Oleh karena operasional PLIK di daerah hendaknya para pengelola PLIK dapat dilibatkan dalam setiap event dan program pemerintah daerah sehingga PLIK dapat berfungsi sebagai stimulator yang tepat bagi masyarakat sekitarnya.

Agar tidak terjadi kesalahpahaman di kemudian hari, status kepemilikan PLIK dan MPLIK supaya lebih dipertegas mengingat perkembangan teknologi yang begitu cepat sedangkan daerah operasional PLIK umumnya di desa yang kurang memiliki infrastruktur baik maka peningkatan kapasitas akses internet perlu dilakukan secara berkala dengan teknologi yang lebih canggih dan cocok untuk perdesaan.

Pendidikan literasi masyarakat agar dilakukan secara terus menerus agar masyarakat perdesaan makin banyak yang dapat memanfaatkan PLIK.

\section{DAFTAR PUSTAKA}

\section{Buku:}

Avanti Fontana. (2009). Innovate, We can!, manajemen Inovasi dan Penciptaan Nilai. Jakarta: Grasindo.

Eko Suhartanto, et al. (2010). Technopreneurship, strategi penting dalam Bisnis Berbasis Teknolog. Jakarta: Kompas Gramedia.
Fandeli, Chafid. (2002). Perencanaan Kepariwisataan Alam. Jogyakarta: Fakultas Kehutanan, Universitas Gajah Mada.

Kemkominfo.

Program KPU/USO.Jakarta: BP3TI.

Meiningsih, Siti, dkk. (2012). Komunikasi dan Informatika Indonesia Buku Putih. Jakarta: Badan Litbang SDM Kemenkominfo.

Rogers, et al. (1995). Communication of Innovations. edisi bahasa Indonesia. Surabaya: Usaha Nasional.

Straubhaar dan La Rose. (2001). Media Now, Communications Media in the Information age, Second Edition, Wadsworth Thomson Learning.

\section{Jurnal:}

Putra, Agus Muriawan.(2006).Konsep Desa Wisata. Jurnal Manajemen Pariwisata, Vol 5, No.1. hal.71-72 .

Okogun O.A, et al. (2012), Economic Value of ICT Investment in Nigeria:Is It Commensurate? International Journal of Economics and Management Sciences, Vol 1, No.10, pp.22-30.

Scheyvens, R. (2000). Promoting Women's Empowerment Through Involvement in Ecotourism: Experiences from the Third World. Journal of Sustainable Tourism, Vol. 8(3), pp. 42-57.

Sumarsono. (2009). Balai Informasi Masyarakat (BIM) Cihideung: Memberdayakan Masyarakat Perdesaan Melalui Teknologi Informasi dan Komunikasi, Jurnal Penelitian Komunikasi, Vol 12 no 1, hal.63-80.

\section{Internet:}

Dinas Kebudayaan dan Pariwisata Kabupaten Sidoarjo.(2010). Sapta Pesona. Tersedia dalam http://pariwisata.sidoarjokab.go.id/sapta pesona.php. Diakses tanggal 25 April 2013.

Linberg, K. (2002). The Economic Impacts of Ecotourism. Tersedia dalam: http://ecotour.csu.edu.auecotour/marl. htm. Diakses tanggal 25 April2013. 